\title{
CINE "NACIONAL"/CIRCULACIÓN TRANSNACIONAL: \\ LA EXPERIENCIA FÍLMICA COLOMBIANA EN EL EXTRANJERO EN AÑOS RECIENTES ${ }^{1}$
}

\author{
"NATIONAL" CINEMA/TRANSNATIONAL DISTRIBUTION: \\ THE COLOMBIAN FILM EXPERIENCE ABROAD IN \\ RECENT YEARS
}

\author{
CINEMA "NACIONAL"/DISTRIBUIÇÃO TRANSNACIONAL: A \\ EXPERIÊNCIA FÍLMICA COLOMBIANA NO ESTRANGEIRO \\ NOS ANOS RECENTES
}

\author{
Por \\ Juana Suárez² \\ www.cinembargocolombia.com
}

Resumen: Esta ponencia aborda el trabajo de cineastas colombianos que producen cine desde diferentes países europeos para entender sus condiciones de producción y circulación. A la luz de teorías sobre cine diaspórico, cine "acentuado" (término acuñado por Hamid Nacify) y cine del exilio, se dilucida si estos paradigmas se ajustan a la experiencia fílmica colombiana en el extranjero o si, por el contrario, tanto para Colombia, como para otros cines latinoamericanos, es necesario pensar nuevas articulaciones teóricas. El periodo que interesa comprende producciones desde el 2000 hasta el año 2015

Palabras claves: Cine nacional, cine transnacional, diáspora, cine intercultural, cine acentuado, cine colombiano en el extranjero. 
Abstract: This paper addresses the work of Colombian filmmakers, who produce films from different European countries, in order to understand their conditions of production and distribution. In the light of theories of diasporic and exilic filmmaking, and "accented" cinema (a concept coined by Hamid Naficy), it seeks s to clarify whether these paradigms fit the Colombian film experience overseas or, on the contrary, both the cinema from Colombia and from other Latin American countries require a new theoretical framework. The works studied range from 2000 to 2015.

Keywords: National cinema, transnational cinema, diaspora, intercultural cinema, accented cinema, Colombian cinema abroad.

Resumo: Este artigo analisa o trabalho de cineastas colombianos que fazem cine desde diferentes países Europeus para entender a suas condições de produção e distribuição. À la luz da teoria sobre cinema diaspórico, cinema "acentuado" (termo cunhado por Hamid Naficy) e cinema do exílio, aclara-se se estes padrões ajustam-se à experiência fílmica Colombiana no estrangeiro ou, ao contrário, tanto para Colômbia, quanto para outros cinemas da América Latina, é preciso pensar novas articulações teóricas. O período de estudo abrange desde o ano 2000 até o 2015.

Palavras-chave: Cinema nacional, cinema transnacional, diáspora, cinema intercultural, cinema acentuado, cine Colombiano no estrangeiro.

Los siguientes apartados hacen parte de una investigación más extensa sobre temáticas, particularidades estéticas y circunstancias de producción que caracterizan el cine colombiano hecho por fuera de Colombia. Una de las premisas básicas es problematizar la nacionalidad del cine colombiano. Por supuesto, hoy día la enunciación de lo "nacional" no tiene que ver únicamente con lo que pasa dentro del país/la nación. Sobra decir que, como cualquier otro cine nacional, el concepto de "cine colombiano" es cuestionable y escurridizo en la actualidad. La producción fílmica que interesa para este proyecto, se piensa a partir de la dislocación y la movilidad, adoptando un ángulo transnacional — sin duda - para pensar y teorizar sobre qué es el cine colombiano y cuál es la extensión geográfica del mismo.

Aunque muchas de las apreciaciones sobre arqueología de la imagen y el concepto de cine intercultural que Laura Marks propone en The Skin of the Film (2000) aplicarían en el caso de estos directores, hay limitaciones. "Intercultural" para Marks se relaciona con un aislamiento diaspórico en el cual el individuo recompone su cultura por medio de los recuerdos sensoriales no visuales, y el conocimiento que éste genera. Esa recreación de memorias del país natal sirve como manera de dar acceso a memorias individuales y culturales que se pueden haber perdido en el transcurso del desplazamiento. Su análisis subraya que el film cobra significado gracias a su materialidad, por medio del contacto entre quien percibe y el objeto que es representado. Sugiere también la manera en que la visión en sí misma puede ser táctil, como si uno tocara las películas con los ojos, lo que viene a denominarse visualidad háptica (Marks, 2000). 
Por su parte Hamid Nacify (2001) categoriza como cine acentuado el cine de exilio/ diaspórico y que resulta de diversas experiencias migratorias. El cine acentuado utiliza el videoarte y el video performance como una de las respuestas a la experiencia de desplazamiento. Como características comunes se puede subrayar la conciencia de una doble identidad, duplicidad del sujeto o de una hibridez, la influencia de varias tradiciones fílmicas (en especial cuando es un cine que se produce en grandes capitales cosmopolitas como Madrid, París, Londres, Nueva York, por ejemplo) y el uso del plurilingüismo. Una experiencia de representación que se hace recurrente es el cuestionamiento del sujeto (que muchas veces es el mismo cineasta) en un entorno escindido, la pertenencia parcial al lugar donde habita y la conciencia de que ya nunca podrá pertenecer por completo al lugar que abandonó.

Mi investigación agrupa a un conjunto de cineastas que se mueven "entre" geografías, lenguas e historias personales/familiares/nacionales. No se trata sólo de residentes en países europeos sino también de aquellos - como Felipe Guerrero, Andrea Said, Vladimir Durán o Martín Mejía - cuyo paso por países europeos ha marcado de forma especial su trabajo para determinar características comunes a sus lenguajes, comparar condiciones de producción y circulación y establecer en qué aspectos se diferencia la experiencia fílmica nacional de la experiencia de hacer cine colombiano en Europa.

Por supuesto, los ejes de esta investigación pueden extenderse a Estados Unidos, Canadá y países Latinoamericanos (Argentina, por su concentración de estudiantes colombianos en las escuelas de cine, sería un caso especial). Este estudio no busca ratificar el lugar de Europa y el eurocentrismo como foco de la cinefilia. Aunque no es el primer texto en proponerlo, ya Unthinking Eurocentrism de Ella Shohat y Robert Stam (1994) cuestionan el privilegio de la mirada europea, el lugar de Europa como "centro de gravedad del mundo, como 'realidad ontológica' a la sombra del resto del mundo" (p. 2) y la manera como empequeñece otros espacios geográficos. Aquí de nuevo se hace problemático el término intercultural de Marks en su referencia a minorías raciales y a grupos suspendidos en el nacionalismo europeo. De este grupo, directores como Ana Salas, Laura Huertas Millán, Nicolás Rincón Guille y Franco Lolli crecieron entre Francia y Colombia.

El periodo de producción de la mayoría de filmes aquí incluidos coincide con la crisis financiera y económica de la Unión Europea que se agudizó desde 2008. Esa crisis ha obligado a repensar políticas, ha generado cambios institucionales y ha desestabilizado la noción que venía funcionando de Europa como actor colectivo. Los cambios institucionales que entraron a operar han tenido un efecto en cómo se percibe la noción tanto de Unión Europea como de país europeo y la legitimidad democrática en varias instancias, con amplia influencia en la manera de percibir el papel de la Unión Europea en los escenarios internacionales. Europa ofrece entonces un punto desde el cual se mira el país con distancia, pero más importante, esta distancia no es heterogénea, como no lo es Europa como zona geográfica, ni lo es la experiencia de la emigración que hoy día es más una experiencia de circulación porque los cineastas regresan con holgura y frecuencia a Colombia o se radican en países terceros en forma temporal o permanente. 
Un primer criterio de selección para esta investigación comprende películas producidas entre el 2000 y el 2015 y examina la producción de una generación nacida alrededor de 1975-1985, con cierta flexibilidad en las fechas. Este grupo de cineastas interesa porque su educación y recorridos están marcados por la manera como el conflicto armado define la Colombia contemporánea. La entrada de pleno del narcotráfico como un actor del conflicto; el debilitamiento de la guerrilla como fuerza ideológica pero no como agente político y económico; el exterminio de la Unión Patriótica; la creciente presencia de fuerzas paramilitares y los controvertidos periodos presidenciales de Álvaro Uribe son, entre muchos otros, eventos y procesos que marcan las últimas tres décadas. Se suma a esto que, a finales de los años 90, la crisis económica en la que se sumió el país fue un factor determinante de emigración de clase media y profesional. Se trata de un periodo de violencia extrema que determina en muchos casos la experiencia migratoria, marcada por el sustrato económico o, en ocasiones, una decisión familiar en la cual los cineastas no tienen poder de decisión, una suerte de "generación que no escogió".

En otros casos, se trata de cineastas que vieron o ven en Europa la posibilidad de producir otro tipo de cine y su desplazamiento no está motivado necesariamente por razones políticas o económicas. En cualquiera de los dos casos, al igual que ejemplos de cine acentuado que Nacify menciona, estos cineastas encarnan no sólo memoria familiar sino nacional en su idea de movilidad $^{3}$.

Del balance logrado hasta el momento, puede decirse que la producción de directores colombianos residentes en Europa se caracteriza por un gran interés en el documental y por una exploración de formas experimentales que en algunos casos combina diferentes medios audiovisuales, en otros interroga los diferentes componentes del aparato cinematográfico, bordeando las aguas del cine experimental y/o del cine expandido, así como definiciones de video-poéticas y tecno-poéticas. De la complejidad de definiciones que encierra el concepto de cine experimental, baste decir que en el campo de esta investigación tiene que ver - a tono con Claudia Kozak (2012) — con “cierta voluntad de juego, de curiosidad por las posibilidades de su propio medio que lleva a los cineastas a una indagación (una experimentación) de/con la forma cinematográfica." (p.42) Por su parte, el cine expandido ha sufrido obvias y grandes variaciones desde su primera definición por Eugene Youngblood en 1970 cuando aún se caracterizaba muy en relación con los formatos análogos y la creciente popularidad del soporte magnético.

En cualquiera de los casos, el grupo de cineastas colombianos que aquí interesa se aventura por nuevas maneras de narrar, sin necesariamente distanciarse de un interés político. Las narrativas fílmicas con frecuencia tienen que ver con temas de dislocación geográfica, una relación nostálgica pero conflictiva con Colombia y diferentes exploraciones en la conciencia de ser colombiano/ latinoamericano y al carácter híbrido de una vida repartida entre Colombia y un país europeo, de nuevo, en algunos casos extensiva a tres o más países. 
Preocupaciones temáticas como la recurrente representación del paisaje en el cine colombiano reciente ameritan una comparación con la producción de estos directores para establecer si hay los mismos fenómenos de exotización, preocupación por el medio ambiente, narrativas de nomadismo, paisaje como escenario balsámico de un supuesto momento de post-conflicto político, o si hay un giro temático o estético. Producciones como Corta de Felipe Guerrero (2012) y Viaje a tierra en otrora contada de Laura Huertas Millán (2009) ${ }^{4}$ parecen señalar una reflexión por una relación colonial que no siempre está presente en el caso del cine colombiano actual, por ejemplo.

Esta investigación indaga cuáles son las variables no sólo de postulados teóricos sino también de forma y contenido: qué género se favorece, qué tendencias estéticas predominan y cómo se dan los circuitos de producción, distribución y circulación. En lo que sigue, escojo tres ejemplos que interesan por su modus operandi y la estética resultante.

\section{Felipe Guerrero: el cine como filigrana}
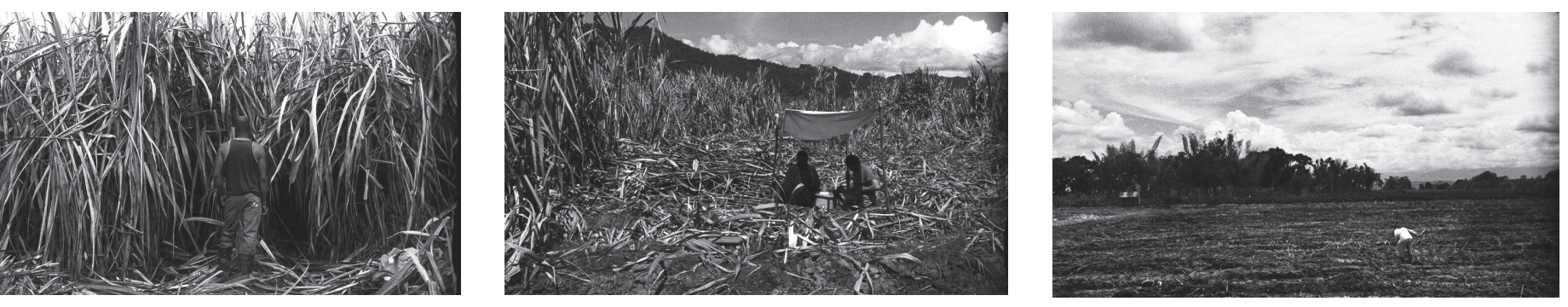

Corta (2012). Director: Felipe Guerrero.

Ante el dominio actual de los soportes digitales, resulta paradójica la insistencia de algunos de estos cineastas por seguir trabajando y experimentando con soportes analógicos. Tal es el caso de Felipe Guerrero, quien reconoce esta inquietud como la gran herencia de su formación en el Centro Experimental de Roma. Su especialización en montaje visita nuevamente ese carácter fragmentario de las imágenes, constante en parte del trabajo de este grupo de cineastas (Salas, Soto y Camilo Restrepo, por ejemplo $)^{5}$. Es una fragmentación que señala la inhabilidad de aprehender el espesor de la historia, pero también de la experiencia de desarraigo. El nomadismo de Guerrero tiene un trazo de niñez entre Colombia y Honduras, luego la experiencia en Italia y su actual locación en Buenos Aires.

Su inquietud por la materialidad, en particular de los pequeños formatos, es la base para cuestionar la sincronía o asincronía entre imagen y sonido que se hace palpable en su corpus fílmico. Aunque más difícil de traducir o plasmar en el lenguaje cinematográfico, Guerrero subraya que su interés por las posibilidades del soporte analógico entra en conversación con su trabajo como lector y escritor de poesía ${ }^{6}$. En su trabajo con el sonido subyace una preocupación por incorporar al cine elementos de la rítmica y la métrica de ese género literario. No es que su cine busque traducir la forma poética, sino que la poesía le ayuda a cuestionar el ritmo de los filmes, buscando 
trabajar con lo sensorial y buscando en el ensayo y la poesía formas que lo alejen de narraciones convencionales de tramas lineales. Es un decidido acercamiento a la videpoética. El cineasta define entonces su propuesta de narración como un proceso establecido en el sonido parasincrónico cuyo "gran sumus" sería Corta (2012).

En su película experimental Paraíso (2006) ya están sentados muchos de estos elementos. Paraíso es un diario de viaje que comprende visualmente acontecimientos de 1948 al 2006. Se trata de un montaje acelerado que no permite al espectador abandonar la pantalla. Guerrero mezcla imágenes contemporáneas filmadas en Súper 8 con imágenes de archivo, revisando en forma crítica el Bogotazo y su continuidad. Paraíso adapta y traduce por diversos tipos de medios el trabajo del movimiento nadaísta, en particular del poeta Jaime Jaramillo Escobar, conocido como X504, y cuyos versos presiden un par de secuencias.

El imaginario sobre Colombia se nutre de noticias, relatos, versiones de los hechos, críticas, imposibilidades de entender lo que pasa en. Paraíso es el resultado de regresar y confrontar de nuevo el país, de intentar exorcizarlo y de cerrar la distancia. Aunque Guerrero hizo un primer corte silente, adicionó posteriormente un mapa sonoro que quiere funcionar en dirección opuesta a las imágenes, pero buscando darle sentido al montaje. Por eso su ritmo entrecortado, hasta cierto punto rabioso y visceral, que denota la imposibilidad de reconciliarse con el país que encuentra en 2006.
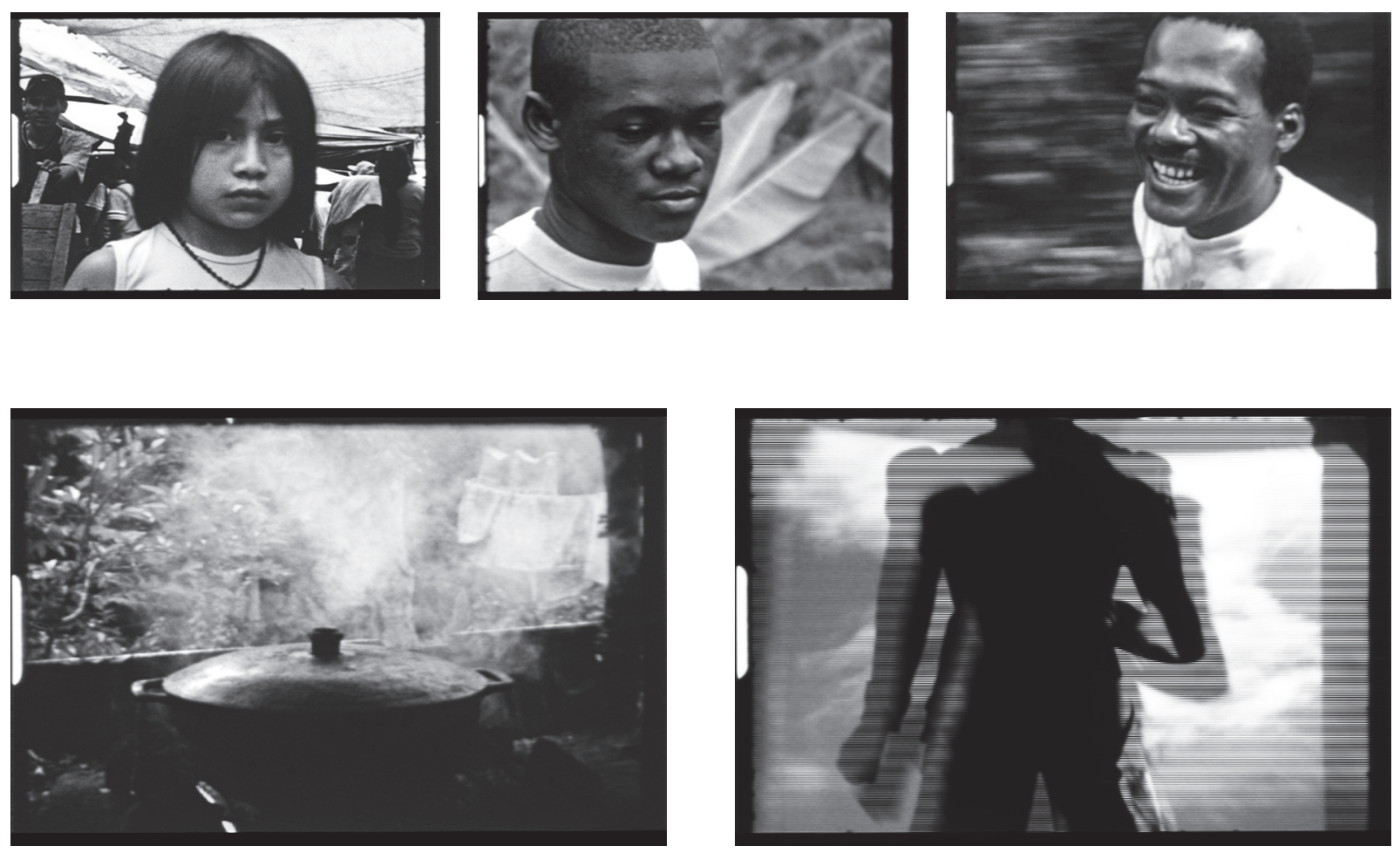

Paraíso (2006). Director: Felipe Guerrero 
El film yuxtapone modos y formatos visuales y de sonido, así como gradaciones de color (resultantes de los varios formatos) para desestabilizar cualquier idea de tiempo fijo y como modo de ilustrar la multiplicidad de motivos que generan violencia. El uso de diferentes formatos cumple varios propósitos; por un lado, genera reflexiones sobre qué efecto tiene representar en una variedad de ellos y qué relación guarda la estética que producen con el momento histórico al que corresponden. El viaje personal de Guerrero se registra en Súper- 8; el archivo de acciones guerrilleras y paramilitares viene casi en su totalidad de archivos en U-matic, hurgando rushes, no productos terminados; las imágenes de eventos más antiguos provienen por lo general de archivos en $16 \mathrm{~mm}$, algunos en $35 \mathrm{~mm}$. La variación de formato proporciona una información técnica que ayuda a emparentarse con diferentes miradas y formas de mirar el conflicto armado en Colombia.

El trabajo con formatos menores es un referente porque para Paraíso no utiliza materiales originales; Guerrero parte de una revisión en MiniDVDs o material que ya ha sido telecinado o digitalizado. En su bitácora de producción, toma atenta nota del formato original para pensar qué tipo de emoción sensorial genera la materialidad específica de cada formato. Su metodología de trabajo para Paraíso es exigente con la revisión de archivos, evitando usar la calidad estética que puede ofrecer lo que ya está comprimido en YouTube u otras plataformas en Internet. Sin embargo, el ejercicio de revisar archivos y pensar en su materialidad específica no tiene como fin hacer una película que sea proyectada en formato análogo; Guerrero tiene plena claridad del presente digital como realidad de la proyección. Su metodología responde a su búsqueda del art film, desde su memoria, desde las memorias y a cuestionar estéticamente como cambia el empaque de las imágenes cotidianas o noticiosas en su textura y granulado y lo que esto pueda decir al espectador.

El tour por la memoria también incluye la palabra, en particular la inclusión de su lectura del Nadaísmo que aparece decantada en la figura de Jaime Jaramillo Escobar. Una grabación previa de la voz del poeta que Guerrero domina algunas secuencias, en forma fragmentaria, nunca como un todo. La presencia del poeta acompaña en forma silenciosa el compendio de imágenes que incluyen entre otras a miembros del gabinete del General Gustavo Rojas Pinilla, protestas civiles en diferentes momentos, imágenes de la toma del Palacio de Justicia, gestos de amor de diferentes personas que interrumpen imágenes de violencia, travellings en Súper-8 por Bogotá, imágenes de la Toma de la Embajada de República Dominicana, recolectores de basura, el botadero de basura Doña Juana, confrontaciones resultado del conflicto en pueblos alejados y mucho más material. Un paneo deliberado de una carnicería preside el acercamiento al cierre de Paraíso mientras que la voz de Jaramillo recita algunos versos de su poema "Alheña y Azúmbar", en específico aquellos versos que disertan sobre las propiedades de la amplia gama de frutas colombianas, advirtiendo los peligros de combinar o emplear erróneamente sus semillas ("pepitas" en el poema). Estos versos sugieren las bondades del país como algo difícil de digerir, como un abanico de combinaciones siempre proclive a intoxicar, lejos de ser cualquier paraíso. "Alheña y Azúmbar” pertenece a los Poemas de la ofensa (1968) de Jaramillo Escobar cuyo tema principal es la muerte. 
Corta (2012), filmado en 6 rollos de 16mm, documenta un día de trabajo en un cañaveral; cada secuencia dura los 11 minutos que permite cada rollo, y se trabaja sin sonido directo. El sonido siempre rompiendo la imagen debe entenderse en este trabajo como la pulsación del país. Sin embargo, no es un sonido que busca el primer plano; por el contrario, atraviesa la narración sin nunca ser subrayado. Por ejemplo, en una secuencia en que aparecen los dos corteros de caña, escuchamos un radio que transmite el bombardeo que causó la muerte del guerrillero Raúl Reyes, el primero de marzo de 2008. Esa grabación proviene de otra fuente y Guerrero la inserta como si la transmisión fuera de modo sincrónico, como un elemento que va anclado a la narrativa. De este modo, se persigue un espectador atento, que ojalá perciba ese ruido que tiene lugar en el trasfondo pero que no afecte la percepción de la película si no lo escucha.

En su estética, Corta antagoniza en forma relativa con Paraíso. Mientras que el pulso del montaje de la segunda es estridente y caracterizado por una euforia rabiosa, Corta se caracteriza por la minucia y reposo de la mirada que, por supuesto, dicta el ritmo del montaje. El acercamiento a los cortadores de caña resulta de un prolongado ejercicio de investigación documental derivado de su intercambio con ellos y la observación de sus rutinas que se plasma en una versión inicial del trabajo en Súper-8, un formato mucho más casero que brinda imágenes más suaves y graneadas, bastante cálido a la vista. Por la duración de los rollos (tres minutos promedio), este formato exige una concepción particular de la rítmica del documental. La versión que Guerrero hizo de Corta en Súper-8 fracasó por el mal manejo del material en un laboratorio en Los Ángeles. Guerrero repitió el ejercicio, rodando en $16 \mathrm{~mm}$. La duración de esos rollos replantea la edición y el trabajo de sonido.

Corta propone una mirada reciente al trabajo de corte de caña sobre el cual existe extensa literatura en las ciencias sociales en América Latina. Es una incursión visual que, a partir de planos fijos, transporta al espectador por un ejercicio repetitivo que se da a lo largo de extensiones de tierra donde persiste el sistema de jornalero, que obliga a campesinos a ganarse un salario dentro del sistema de distribución del capital de la hacienda. Los planos fijos enfatizan el trabajo autómata que solo concluye con la carga de volquetas que se pierden en polvorientos caminos.

Corta no fue sólo concebida como un trabajo fílmico sino como instalación artística, basada en un concepto que Guerrero acuña como “espacialización del sonido.” Su apreciación exacta invoca la proyección pública en una sala de cine que permita que el sonido invada el entorno y se experimente ese tempo que va de lo lento en los primeros rollos - el registro de llegada e instalada en la jornada laboral - a un tempo acelerado (el corte en sí de caña) y al reposo en la culminación del día. Esta imagen de cierre entra en conversación con la historia de la documentación de la salida de la fábrica que, desde los orígenes del cine, desde La salida de la fábrica (Louis Lumière, 1895), casi siempre es representada como euforia, liberación temporal y regocijo. 
En Corta hay una pesadumbre que también convoca a la posibilidad de que el trabajo fílmico sea un espacio expositivo, donde la aproximación a ese mundo de los corteros ya no sea secuencial o lineal como en el cine sino simultánea como en el museo. Es imposible ver Corta y no divisar su conversación visual con la instalación en vídeo de Harun Farocki Trabajadores saliendo de la fábrica durante once décadas (1995) ${ }^{7}$. Dice Farocki:

El montaje del film tuvo sobre mí un efecto totalizador: una vez que tuve el montaje a la vista, me asaltó la idea de que el cine había trabajado durante cien años sobre un único tema. Como si un niño aprendiera a repetir la única palabra que aprende a decir durante cien años para inmortalizar la alegría de poder hablar. O como si el cine siguiera los pasos de los pintores del lejano oriente que siempre pintan el mismo paisaje hasta alcanzar la perfección e incorporar al artista. El cine se inventó cuando ya no se podía creer en esa perfección. (p.201)

El trabajo de Guerrero se constituye como una espesa pero delicada filigrana que apela a la vista, a la razón, a la escucha, a lo racional y a lo irracional. Proviene de una incesante conversación con el cine, con sus sorpresas y sus desafíos, pero de nuevo, con Farocki en mente, de una gran desconfianza de las imágenes que hace del trabajo de este cineasta uno de los más complejos y ricos, proclive a ser desglosado en muchas capas, percepciones y significados.

\section{Laura Huertas Millán: inventarse el trópico y cuestionarlo}
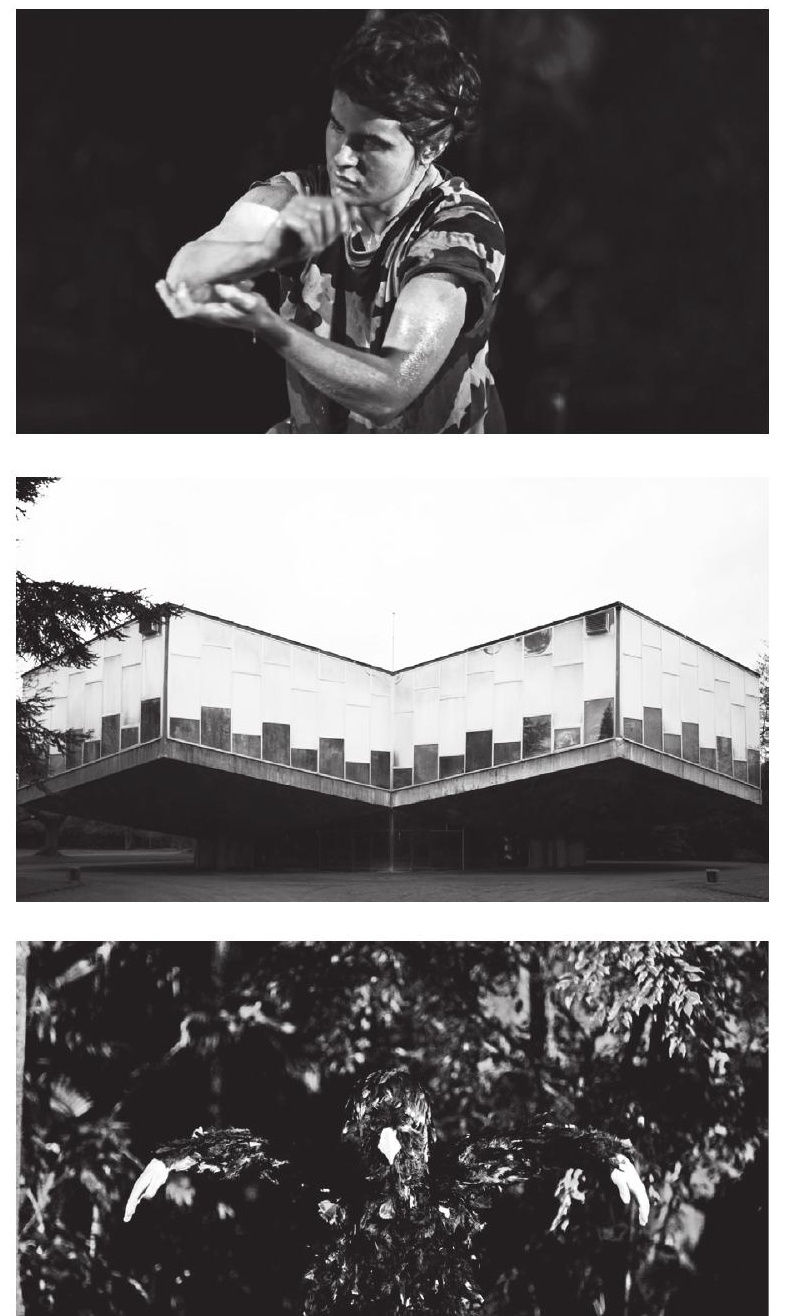

Viaje en tierra otrora contada (2012).

Directora: Laura Huertas.

El trabajo de Laura Huertas Millán es difícil de catalogar como documental, pero tampoco se trata de narraciones argumentales. Huertas trabaja a un nivel muy simbólico, de una forma muy lúdica, pero también con una concepción muy crítica, en un cine que se desvía mucho de narrativas convencionales. Se trata de producciones visuales ricas en alusiones a las ciencias sociales y humanas, sin ser dogmáticas. Sus trabajos tienen una fuerte armazón en una mente curiosa e intelectual que no da reposo a la investigación. Sin embargo, como veremos, tampoco satura conceptualmente su acercamiento al cine sino que, por el contrario, lo alimenta de formas sagaces y desafiantes. 
Como parte de su trabajo artístico, Huertas Millán mantiene una intensa agenda de estudios, nutrida por becas y pasantías y que determina su estancia entre Colombia, Francia y Estados Unidos. Es candidata a doctorado en la Escuela Superior de Bellas Artes de París y hace una pasantía en el Sensory Ethnography Lab y el Film Study Center de la Universidad de Harvard. Huertas se reconoce abiertamente como un ser escindido, que responde a dos nacionalidades diferentes y que busca con frecuencia unir las dos partes de ese fraccionamiento en su trabajo. Sin dejar huella (2009) y Viaje en tierra otrora contada (2012) fueron filmados en dos jardines botánicos franceses que se erigen como memoria de procesos coloniales. El primero en el Jardín Tropical de París, cuyo nombre traduce literalmente Jardín de Agronomía Tropical (Jardin d'Agronomie Tropicale), un espacio de 4.5 hectáreas, que data de 1907 como parte de las exposiciones coloniales, entonces normativas para los estados colonizadores europeos, ahora bastante problemáticas. El Jardín Tropical fue construido por la Sociedad Francesa de Colonización, reproduciendo a escala seis de los territorios colonizados por Francia: Indochina, Madagascar, Congo, Sudán, Túnez y Marruecos. Su espectáculo corresponde al tipo de parques de diversión que abundaron durante las exposiciones universales o como derivado de ellas, en el giro del siglo XIX al XX y que contenían a menudo los denominados "zoológicos humanos", reproducciones a escala donde los europeos disponían de nativos de sus colonias como objetos de exhibición para mostrar cómo eran sus vidas en "sus condiciones "naturales".

Viaje en tierra otrora contada se filma en el Jardín Botánico-Sierra Ecuatorial de Lille, edificio construido en 1970 por Jean -Pierre Secq como un palacio de cristal. Esa figura le sirve a Huertas para evocar la figura de Alicia en el país de las maravillas y de Alicia en el espejo y proponer un viaje inverso. Ese espacio cerrado sirve como soporte para el recorrido narrativo de un explorador, evocando el "Nuevo Mundo" y las imágenes que generó. Se constituye entonces como una ficción documental que parte de relatos y descripciones hechas por los primeros viajeros y colonizadores europeos en América. Este trabajo navega tanto en las aguas del cine expandido como del videoarte y responde temática y formalmente a las preocupaciones de Huertas, así como a posiciones que quiere sentar. Por un lado, está la escisión ya mencionada, resultante de su desplazamiento. Por otra hay un cuestionamiento a la historia y a su lenguaje autoritario y patriarcal y a la exotización de territorios colonizados, que bien pueden ser América Latina pero también es aplicable a Asia o a África.

Las réplicas de lugares tropicales interesan a Huertas Millán como espacio para cuestionar las narrativas de la historia, devolviéndole la pregunta con un dispositivo artificial. Viaje en tierra otrora contada es una crítica radical a los falsos trópicos. Interesa aquí el concepto de una naturaleza construida, intervenida para representar en Lille climas tropicales que sólo se han acercado a la metrópolis europea como flujo de capital y fuerza de trabajo. El ejercicio visual consiste entonces en hacer del Jardín Tropical una falsa selva para convertirlo en un vivero tropical que es temporalmente un set de cine y hace, por ejemplo, lo que hace el cine comercial de Hollywood: transmitir una imagen adulterada del espacio que al convertirse en parque de atracción físico o visual intenta borrar la memoria histórica colonial. 
Viaje guarda estrecha conexión con la lógica política subyacente detrás de los textos de viajeros, en particular de las Crónicas de Indias y relatos coloniales que entre el siglo XVI y XIX reportaban a la Corona española sus expediciones en forma de diarios, relaciones, cartas y testimonios. La directora adapta libremente textos de Voyage sur l'Amazone, de Charles-Marie de la Condamine (Francia, 1743-1744); Nus féroces et anthropofages, de Hans Staden (Alemania, 1557) — el mismo texto que da origen al clásico latinoamericano Como era gostoso o meu francês, del brasileño Nelson Pereira dos Santos (1971); Historia verdadera de la conquista de la Nueva España, de Bernal Díaz del Castillo (España, 1632); Histoire d'un voyage fait en la terre du Brasil, autrement dit Amérique, de Jean de Léry (Francia, 1578) y La mission d'Ibiapapa, del Padre Antoine Vieira (Portugal, 1657).

Huertas Millán visita textos de estamentos del poder eclesiástico, militar y científico. Varios elementos señalan la manera como la cineasta los desacraliza y al mismo tiempo les responde: la adaptación libre y el desordenamiento de las citas, la ausencia de citas precisas de las fuentes, el tono solemne y performativo del narrador que lee en voz alta esta distribución caprichosa de versiones. En forma paródica, se conserva el lenguaje colonial y la lógica de organización episódica que caracteriza a la mayoría de esos textos, relaciones y bitácoras. Como diría Marks (2000), "el acto de excavación llevado a cabo (performed) por estos trabajos es primariamente reconstructivo, pues es necesario desmantelar las historias coloniales que enmarcan las historias de las minorías antes de que ellos puedan contar esas historias en sus propios términos" (p.25).

Aequador (2013) se deriva de material filmado por Huertas Millán en varios viajes por el Amazonas como proceso de inmersión para hacer Viaje en tierra otrora contada. Aquí cabe resaltar que, aunque la cineasta presta herramientas del cine etnográfico, su trabajo en ningún momento espera enfilarse en esa categoría. No obstante, la inmersión, la cohabitación y la observación son procesos que preceden sus trabajos fílmicos e informan sus proposiciones estéticas. Su interés en estos tres trabajos es explorar la estética y ontología del mundo natural a partir de elementos visuales y acústicos que no confían en lo escrito. Al mismo tiempo, prestan elementos de su formación como artista para alejarse de la antropología visual y de las mismas prácticas discursivas de la antropología. No es una crítica de la cineasta ni al cine etnográfico ni a la antropología sino, por el contrario, un reconocimiento de que no son sus campos de operación y que es el ejercicio de la escultura y sus muchas capas, el concepto estético que alimenta su trabajo visual. Al mismo tiempo, para Huertas Millán el cine representa el desafío de traspasar la rigidez de su cultura visual que está muy cimentada en la pintura y la fotografía.

Aequador retoma imágenes de esa travesía por el Amazonas y las combina con memorias de conversaciones con su padre Miguel Huertas, artista y profesor de arte en la Universidad Nacional. Una de las preocupaciones investigativas de Miguel Huertas ha sido cuestionar los cimientos de la Facultad de Artes de la Universidad Nacional de Colombia, haciendo escrutinio de los patrones importados para la concepción, crítica y pedagogía del arte, los paradigmas que se incorporan con los modelos de periodicidad y generaciones, y la ideología que respalda esos patrones. 

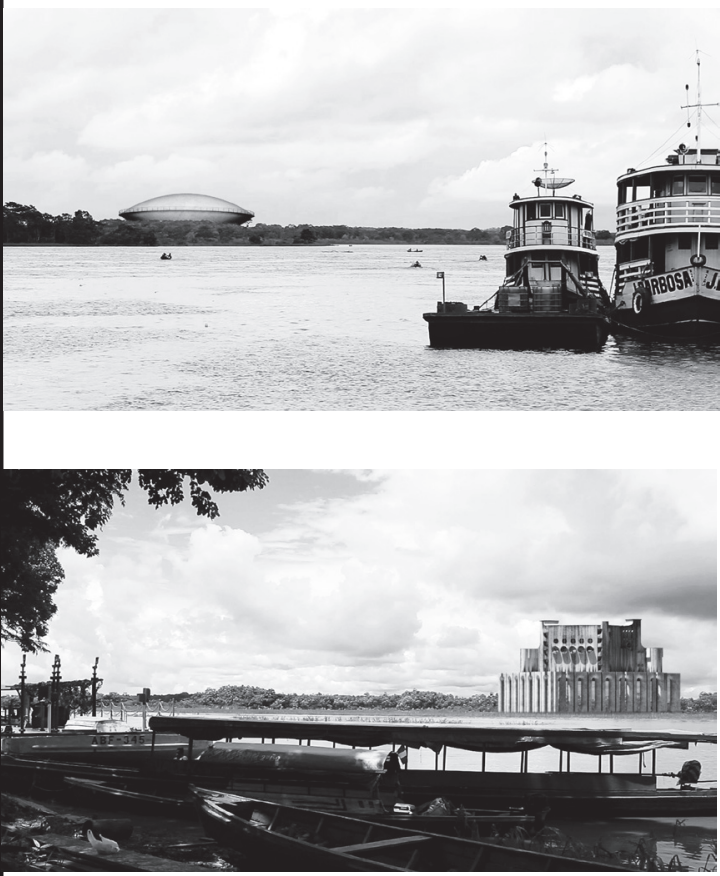

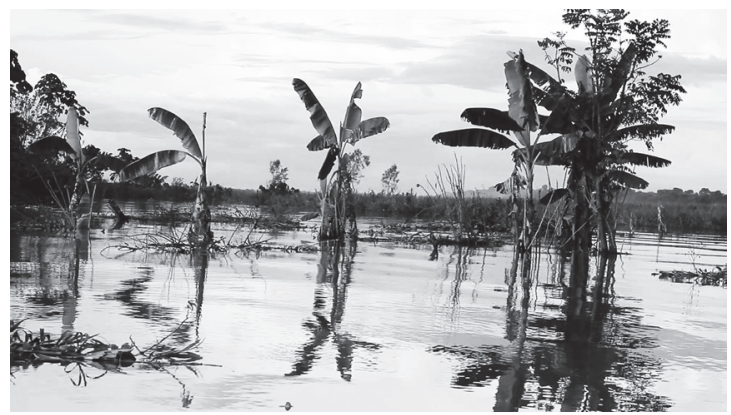

Aequador (2013). Directora: Laura Huertas Millán.

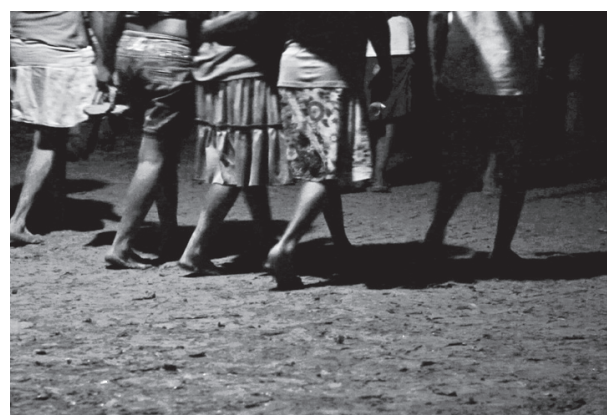

Aequador propone la conjunción de dos lugares separados por el tiempo y la geografía que retorna a la forma del diario de viaje colonial pero ahora reemplazando las palabras y las abarrocadas formas de relación por imágenes. La cámara atraviesa un paisaje atestado de construcciones modernistas desoladas, residuo de una utopía del pasado sepultada por la naturaleza. Las imágenes son logradas con un cuadro tridimensional que cumple el cometido de transponer edificios que recuerdan la agresiva arquitectura brutalista de Europa Oriental a la selva pero que también cita las fantasías futuristas de arquitectos como Oscar Niemeyer.

Huertas describe Aequador como "una ucronía que entrelaza realidad y ficción, que evoca los excesos de ciertas políticas modernizadoras en América Latina durante el siglo XX y su cohabitación con el presente." ${ }^{8}$ El recorrido por el Amazonas aparece precedido por un texto del poeta José Fernández, narrador ficticio de De sobremesa de José Asunción Silva (Colombia, 1865-1896) y que es libremente adaptado por la cineasta.

Esta cita ya está cargada de significados sobre el poder de la escritura como ley y como norma, y el poder de la arquitectura como escritura de la ciudad y del proyecto modernista en América Latina. De sobremesa es una contestación crítica al proyecto de Regeneración de Rafael Núñez a finales del siglo XIX. El escritor utiliza la máscara del poeta Fernández para conformar, entre saltos de lo literario a lo histórico, una crítica a un proceso que a su modo de ver era totalitario. Con la narración del acaudalado poeta Fernández, Silva establece en la novela un puente imaginario entre dos lugares distantes, la Bogotá y las metrópolis al otro lado del Atlántico, en particular Londres, París y Ginebra, cuya distancia es mediada por el sinnúmero de descripciones que contrastan la afeada capital colombiana con una ciudad europea idealizada y construida en su imaginación desde el derroche y el exceso de lo sensual. 
En Aequador la cámara recurre a los travellings para dar la idea de desplazamiento en contraste siempre con planos extremos que se detienen, por ejemplo, en las manos de un indígena, en un barco o en una pareja de insectos. Surge de nuevo el cuestionamiento sobre la sedimentación de las múltiples capas con que se trabaja en escultura y la manera cómo podrían traducirse a la imagen en movimiento; en otras palabras, las intervenciones arquitectónicas futuristas abandonadas en el Amazonas, aparecen como ilusiones ópticas, como fantasmagorías que interrumpen la naturaleza y cuestionan el pasado y el presente. El paisaje no está despoblado sino, por el contrario, copado por los habitantes del lugar, sus rutinas y sus rituales que conviven con estos enigmáticos edificios, representados en pantalla siempre como un telón de fondo silencioso pero que dice mucho. Aequador pone en ciernes la idea de civilización y la voluntad de mestizaje, desafiando la relación entre naturaleza, hombre y arquitectura.

En estos tres trabajos, predomina la perspectiva de una viajera que cuestiona el vínculo con el país natal, idealizado en la distancia, convertido en una especie de fantasma de la memoria, pero confrontado en el reencuentro que no siempre es físico. Los viajes por la historia, las lecturas, la misma distancia, la sospecha sobre la mirada europea de América se vuelven maneras de regresar a Colombia y material para la experimentación visual y narrativa. Viaje en tierra otrora contada y Aequador no son sólo trabajos que cuestionan la historia, sino que también proponen interpretaciones. En ellos, la historia es un tema recurrente que conlleva a una reflexión política distribuida en la manera cómo se cuestionan los procesos de colonización y sus secuelas; la huella más grande de estos procesos es la exotización del otro y su paisaje, que intenta reprimir la memoria del dolor y la violencia por medio de artificios. En los dos trabajos, se parte siempre de una desconfianza de la imagen que representa al otro en el espacio otro, entendiendo que quien lo capta tiene el poder de la tecnología para materializar su fascinación, pero no puede dejar de violentar la dignidad del sujeto etnográfico.

El trabajo de Huertas Millán osa escudriñar espacios y hace preguntas que no han sido recurrentes en el corpus de cine hecho por mujeres colombianas, un espacio visual donde sin duda son bienvenidas propuestas más científicas, creativas y que no tengan duda al cuestionar cómo se ha escrito la historia.

\section{Juan Soto: Editar cine, editar la vida}

$\mathrm{Al}$ centro del trabajo de Soto subyace la ecuación entre cómo se edita una película y cómo se edita la vida. Estudio de reflejos (2014), su último documental, no sólo lo hace muy explícito, sino que señala que esas disquisiciones hacen considerar la obra del director como un work in progress, una pregunta constante sobre qué es hacer cine

y cómo hacerlo. Soto, además, advierte que su trabajo es cine en video, no cine en formatos análogos como él quisiera, experiencia que le daría otra información háptica y le generaría otra suerte de reflexiones. 


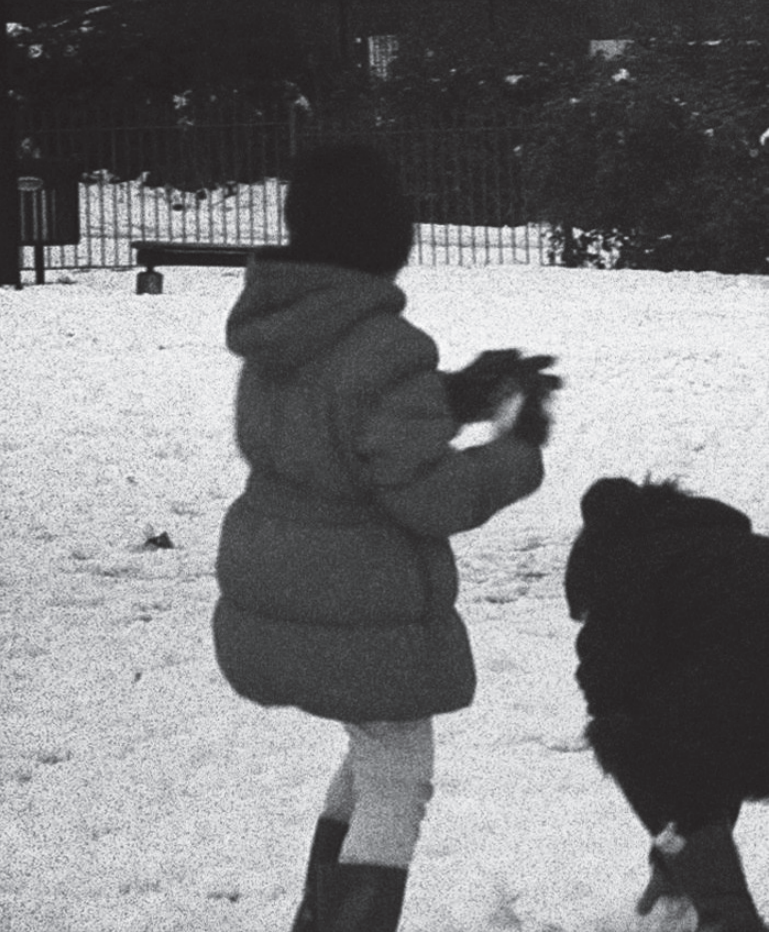

Nieve (2012).

Director: Juan Soto.
Graduado de la Escuela Internacional de Cine y Televisión de San Antonio de Los Baños (Cuba, 2007-2010), su vida en Europa abarca temporadas en España, Alemania y una extendida permanencia en Inglaterra. Su emigración guarda relación con su vida privada (su novia Chiara Marañón trabaja para MUBI -Inglaterra) y atenúa otras razones que, si bien no son necesariamente políticas, tienen que ver con marcos institucionales para promover la industria fílmica más flexibles, abundantes y descentralizados. Incluso si la financiación de sus trabajos ha sido hasta ahora mayormente personal, Soto reconoce la infraestructura de producción inglesa como proveedora de una independencia que se complementa además por la exposición a una oferta cultural que es mucho más limitada en América Latina.

En sus trabajos más conocidos $19^{\circ}$ Sur $65^{\circ}$ Oeste (2010), Oslo (2012), Nieve (2012) y Estudio de reflejos (2013), Soto trae a la edición elementos de su archivo familiar y el archivo de noticias; esto se mezcla con situaciones y conversaciones con Marañón y escenas de la vida diaria. "El espejo está roto pero ¿qué revelan sus trozos?", la cita de Bergman que acompaña Estudio de reflejos dice mucho de su concepción del cine: la vida íntima, diaria y familiar fragmentada como material cinematográfico.
Desde $19^{\circ}$ Sur $65^{\circ}$ Oeste, el uso del archivo casero se configura como una manera muy abstracta de explicar su historia familiar, una atención además muy ligada a las cicatrices de la desaparición de su tío Wilson Mario en 1987 y a la relación de su familia con el tío Caliche que, bajo otra identidad y residiendo en otro país, ha logrado escapar legítimamente no sólo de sus cuentas pendientes con el país sino con su militancia en la Unión Patriótica.

A partir del rescate de una compilación de memoria familiar circulante en un VHS de intercambios con el tío Caliche, en $19^{\circ}$ Sur $65^{\circ}$ Oeste - su trabajo de grado para la EICTV — Soto intenta desenmarañar para sí mismo la historia del tío, pero la complica para el espectador, como lo hace en sus otras producciones. $19^{\circ}$ Sur $65^{\circ}$ Oeste es una historia de reencuentro con el tío Caliche, residente en Uruguay, que cobra un viso fantasmagórico en la cotidianidad de la familia Soto Taborda. Caliche aparece en llamadas, correspondencia epistolar a veces acompañada de las imágenes que logran perdurar en el VHS y los acompaña más como un rumor, como un secreto, como un recuerdo de una foto familiar que, aunque proclive a estar completa de nuevo alguna vez, ya nunca lo estará. $19^{\circ}$ Sur $65^{\circ}$ Oeste (2010). Director: Juan Soto.
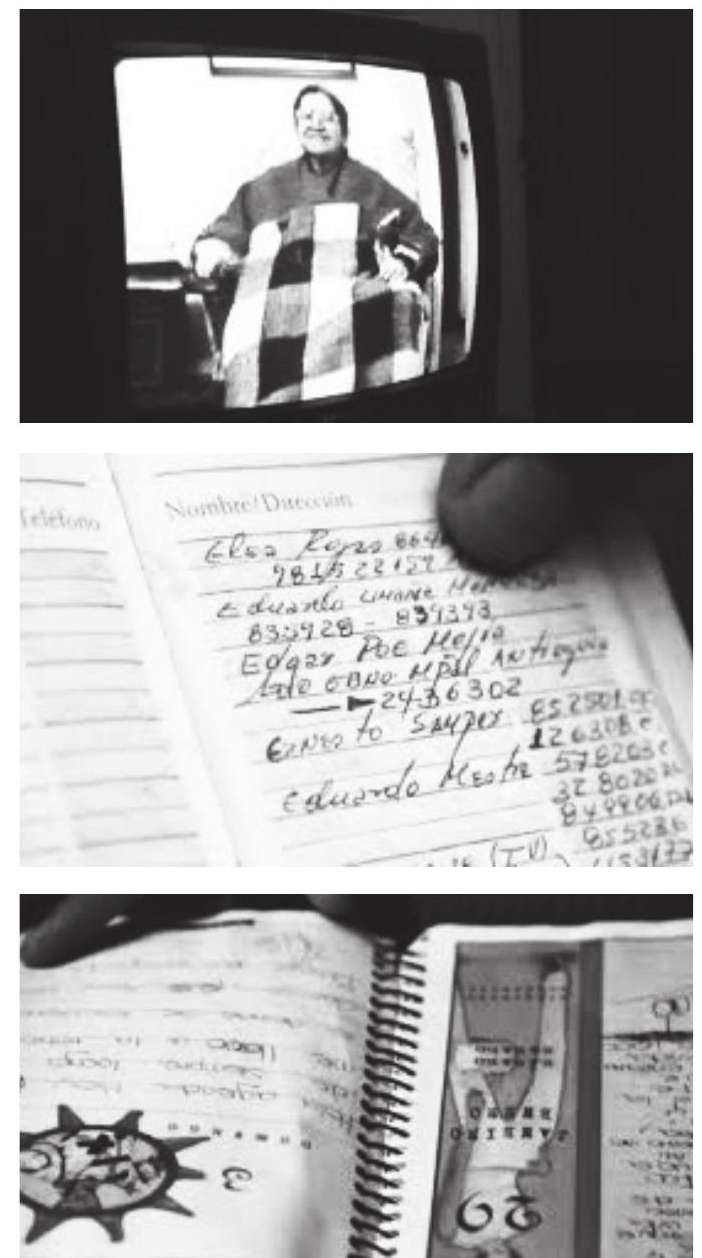
El desafío estético para Soto radica en presentar un documental autobiográfico que recoja lo que él puede aprehender de esta historia de vida y de esta historia de su familia que surge a partir del rumor, del hablar quedo, de nunca dar una explicación a Soto y a su hermana de quién es el misterioso personaje que solo aparece como voz en llamadas telefónicas o mediado por la pantalla. $19^{\circ}$ Sur $65^{\circ}$ Oeste documenta el viaje de Soto a Montevideo (Uruguay) con el propósito de adjudicar una corporalidad a esa presencia. Las secuencias del documental responden a una estructura de diario que no se lleva prolijamente con entradas seguidas, sino que van resumiendo los avances del viaje. El encuentro con Caliche en las primeras secuencias es distante e incómodo; el sujeto del documental coincide con el director involuntariamente al preguntar "¿qué hay que decir, qué no hay que decir?", una pregunta que auto-edita y hace manifiesta las secuelas de la censura familiar y política.

Soto aborda al tío Caliche desde la rutina cotidiana y captándolo progresivamente, como una serie de fragmentos corporales que cobran unidad poco a poco. Primero las manos preparando un café, haciendo una torta, luego el volumen de su cuerpo visto borroso desde la distancia, fragmentado, presentando el torso o la espalda hasta animarse a ofrecer una imagen completa a la cámara. Si bien estos elementos estilísticos pueden ser una respuesta a la censura tácita de la familia, también son aprendidos de la cinefilia de Soto, marcada por un interés particular en el documental personal con Chris Marker, Jonas Mekas, Johan van der Keuken, Agnes Varda, Victor Kosakowski, Alan Berliner, Chantal Akerman, Naomi Kawase, Patricio Guzmán y José Luis Guerín como documentalistas de cabecera.

Como en casi todos sus trabajos, Soto no apunta, no señala. Su cámara sugiere, incita e invita. En $19^{\circ}$ Sur $65^{\circ}$ Oeste, en lugar de perderse en cuestionamientos o disquisiciones políticas, el tratamiento de lo político se desplaza a un objeto: una vieja agenda telefónica sobre la cual no se revela si Soto la ha traído o Caliche la conservaba. Por sus páginas desfilan nombres de personajes políticos que recomponen el espeso panorama político de Colombia entre 1980 y 2000. Como claves cifradas en un archivo, Caliche lee en voz alta los nombres de políticos de los partidos tradicionales en Colombia y otros de miembros de la extinta Unión Patriótica: Jaime Pardo Leal, Teófilo Forero, Braulio Herrera, Belisario Betancur, Ernesto Samper Pizano, Eduardo Umaña, Álvaro Salazar y Fernando Botero Zea. Uno de ellos es Caliche, pero es trabajo para el espectador descubrirlo, abordarlo, entenderlo. No del cineasta.

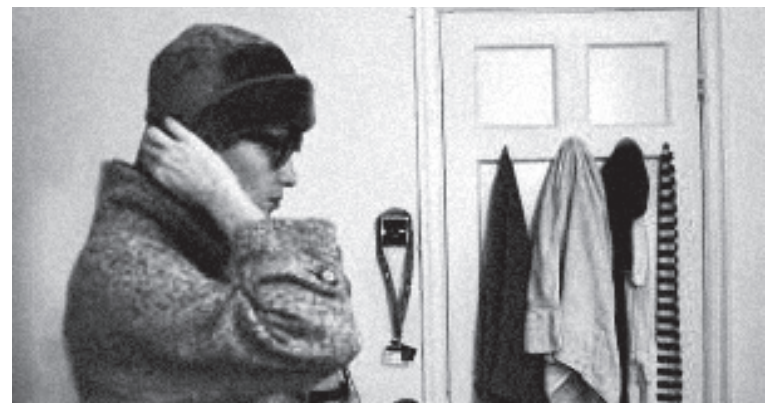

Nieve (2012). Director: Juan Soto.

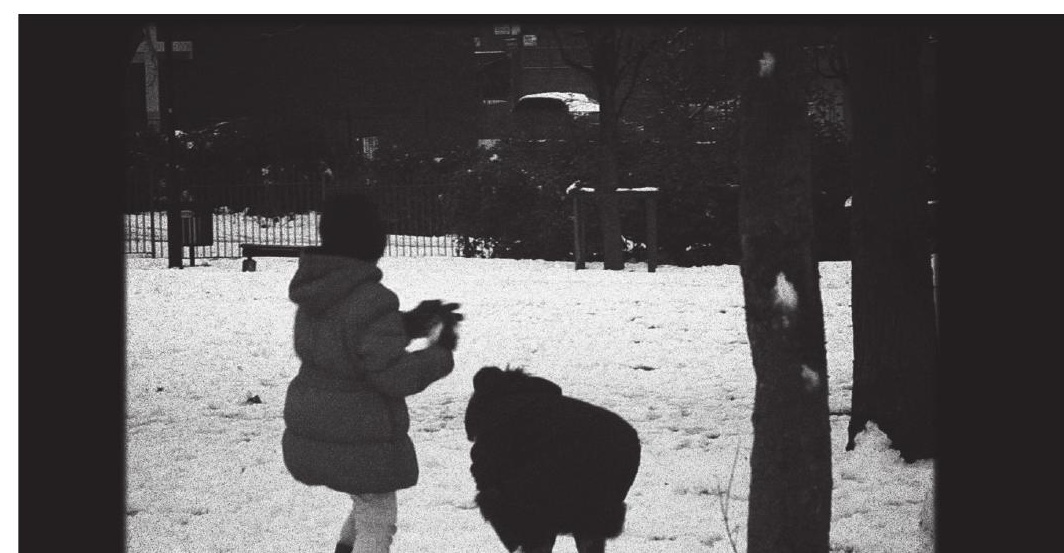


Soto concibe la memoria familiar como un archivo recuperado de la negación, también familiar. Cabe en este ejercicio una apreciación de Michael Chanan (2008) sobre el archivo:

Puesto el funcionamiento del archivo, no obstante, no puede ser separado de sus substratos, también se hace una pregunta cómo estos substratos [los que lo componen] son almacenados y cómo se da el proceso de retirarlos. Por tanto, tendríamos que hablar de los archivos como una institución con una cierta estructura de economía, el acceso a ellos como un proceso de investigación. Y descubrimientos. El archivo es un espacio de paradoja, un repositorio de objetos de memoria donde pueden dejarse y abandonarse. (p.257)

La gran cicatriz aparece enmarcada por un epígrafe de Emil Ciorán: "Si no quieres sucumbir a la rabia deja la memoria tranquila. Renuncia a hurgar en ella”, esta cita se extiende a todo el trabajo de Soto. Desafiando el silencio de una familia con un convulsionado pasado y presente político, Soto cuida que la memoria de su familia y el contexto en que está enmarcada no se descuide por mucho tiempo; el pretexto de hacer cine le ha servido para hurgar ese archivo, para cuestionar y recordar pero no para alimentar rabia o dolor, sino para tratar de esclarecer, de dar lugar a la memoria.

En Estudio de reflejos un eje amplio es la transformación de la mirada. Pedro Adrián Zuluaga lo describe como "culminación hasta el momento [2014], de una obra de trazos personales que se sostiene en la memoria y el archivo, en el cine y la fotografía, en la mirada." ("Estudio de reflejos"). En un trabajo fílmico que funciona alrededor del concepto del espejo, de su diseminación de imágenes al romperse como una alegoría para la familia separada, extendida, disgregada por varias partes y sobre todo del viaje de la mirada. Soto retoma sus obsesiones y sus motivos visuales predilectos para dar una estructura de viajes que narran un regreso con Chiara a España y una separación temporal de ella para pasar tiempo con su familia en Colombia. La serie de desplazamientos está signada por la obsesión de filmar la cola del avión, travellings en auto, el tiempo en la carretera; un sin fin de movimientos que recuerda uno de los temas puntuales del comienzo del cine y su éxtasis en hacer que la imagen esté literalmente en movimiento.

También aquí Soto regresa al cine casero, retomando un material en video 8 que filmaron los Soto Taborda con la primera cámara que tuvo la familia. Las visitas al material casero se van amoldando en la filmografía de este director como una forma de quedarse, no en un espacio sino en un tiempo, en momentos de su familia. Son imágenes que en su reciclaje van ganando más aire de nostalgia y que se transforman y cobran nuevos significados cada vez que Soto las retira del archivo y las pone a conversar con nuevas preocupaciones, con nuevos trozos visuales. 
Estudio de reflejos resulta de un taller con Abbas Kiarostami que se centra en la capacidad de observación como piso para hacer cine. En su tarea, Soto convoca personas y elementos que argumenta como una razón para estar en Europa: Chiara, la exposición a una oferta fílmica más amplia y desplegada en cinetecas, muestras, festivales, tiendas de libros especializados, conferencias físicas o virtuales, encuentros de primera mano con directores que admira, como Raya Martin en este caso. Sugiere, al mismo tiempo, este espacio de separación del país como cuestionamiento a la condición de extranjero pero, en forma sagaz, no lo hace a partir de sí mismo. En esta suerte de diario de viaje, Soto opta por desplazar las preguntas a la voz de Chiara, a su extrañamiento ante el país vasco, el euskera y a las mismas reflexiones posteriores de los Marañón sobre el catalán. Mientras tanto el cineasta va filmando, captando reflejos, observando como los demás toman fotos de familiares y otra gente, haciendo un ejercicio que aparece en mimesis con el suyo, tanto en su estudio de encuadres y marcos cuidadosos, combinados con otros más casuales. El director aparece aquí no sólo fascinado por su propia mirada sino por la manera como otros miran con la cámara.

Esa "culminación temporal" de la que Zuluaga habla, termina para Soto en el Festival de Cine de Santa Fe de Antioquia. Allí, él mismo juega con la idea del director invitadola misma que ha captado con otros directores momentos previos en Estudios-y del crítico (Santiago Gómez) que lo presenta con desbordados elogios. El que aparece como un momento público pronto regresa a lo familiar con el reconocimiento de Soto a la presencia de sus parientes entre el público. Aquellos parientes que son imágenes presentadas en sus vídeos caseros, que figuran al azar en sus otros trabajos son celebrados aquí como parte integral de su aprendizaje, de su carrera fílmica.

Así pues, sirvan tres ejemplos para ilustrar dislocaciones geográficas que desestabilizan el concepto de cine nacional mientras circulan por espacios transnacionales, que no se reducen solo a geografías, sino que incluyen cuestionamientos a modos de hacer cine, interrogaciones a lo personal y a la historia.

\section{Notas}

${ }^{1}$ Este artículo se origina en la ponencia presentada en el Seminario Crítica y Análisis de Cine Colombiano, organizado por la Cinemateca de la Universidad del Valle (Cali, Colombia) realizado del 28 de septiembre al 2 de octubre en la Universidad del Valle.

${ }^{2}$ Doctora en Literatura Latinoamericana, Magíster en Literatura Hispanoamericana y Magíster en Archivo y Preservación de la Imagen en Movimiento. Se especializa en restauración y preservación analógica y digital de archivos fílmicos y en cine, literatura y estudios culturales latinoamericanos. Es autora de Sitios de Contienda. Producción Cultural y el Discurso de la Violencia (Madrid, Iberoamericana-Vervuert, 2010) y Cinembargo Colombia. Ensayos críticos sobre cine y cultura colombiana (Cali, Universidad del Valle, 2009), publicado en inglés por Palgrave en 2012. Actualmente, está adelantando un proyecto de investigación titulado Film Archives, Cultural History and the Digital Turn in Latin America y una investigación sobre cineastas colombianos y movilidad transnacional. www.cinembargojuana.com

${ }^{3}$ Nacify se ocupa principalmente de cineastas que crecieron en países del llamado tercer mundo y han trabajado en Europa como Trinh T. Minh-ha, Ghasem Ebrahimiam, Mira Nair, y Ann Hui. También incluye cineastas que crecieron en Europa, pero cuya carrera se ha caracterizado por el desplazamiento como Chantal Akerman, Atom Egoyan, Nina Menkes y Chris Marker. 
${ }^{4}$ El título Voyage en la terre autrement dite de Huertas Millán aparece traducido al español de varias maneras. Me ciño aquí al utilizado en el enlace de vimeo de la directora.

${ }^{5}$ Camilo Restrepo es otro director colombiano que interesa para una versión a largo plazo de este trabajo. Residente en Francia, su trabajo tiene muchas intersecciones con el grupo de cineastas incluido en esta investigación, pero una mayor afinidad con cineastas como Guerrero por la materialidad del medio fílmico y el trabajo con archivos. Se encuentra también con Huertas Millán en, como veremos, la preocupación por hermenéuticas preconcebidas sobre espacios geográficos. Al respecto, interesan sus trabajos experimentales: Como crece la sombra cuando el sol declina (2013), Tropical Pocket (2012) y La impresión de una guerra (2015).

${ }^{6}$ Entrevista personal.

${ }^{7}$ FAROCKI, Harun. Desconfiar de las imágenes, Caja Negra, 2013, Buenas Aires. La obra en cuestión parte de la conocida película de los Hermanos Lumière La sortie de l'usine Lumière à Lyon (1895), para realizar una investigación sobre el tratamiento del tema de la salida de los obreros de la fábrica en la historia del cine. Según Farocki, la fascinación por el registro del movimiento hizo que la primera cámara de la historia filmara la salida de unos trabajadores, ordenados y alineados de forma artificial por un director de cine. Sin embargo, mucho antes que el cine, el orden industrial se había encargado de sincronizar al sujeto. Tras una larga investigación arqueológica entre una extensa cantidad de material fílmico, Harun Farocki selecciona doce películas, las fragmenta y reduce únicamente a ese momento para exhibirlas. yuxtapuestas de forma cronológica en doce monitores de televisión. Con esto, realiza una traslación al espacio físico del tradicional montaje cinematográfico, el cual da un paso más allá y se transforma en una instalación simultánea que crea un efecto caleidoscópico y totalizador. Mediante esta película multicanal, Farocki busca reflexionar sobre la organización de la vida en la sociedad industrial, a la vez que meditar sobre el cine como medio de construcción de sus representaciones.

8 http://www.bienaldeartesmediales.cl/12/ciclo_cine/aequador/

\section{Referencias}

Chanan, M. (2008). The Politics of Documentary. Londres: British Film Institute.

Kozak, C. (2012). Tecnopoéticas argentinas. Archivo blando de arte y tecnología. Buenos Aires: Caja Negra.

Marks, L. (2000). The Skin of Cinema. Intercultural Cinema, Embodiment and the Senses. Durham: Duke UP.

Nacify, H. (2001). An Accented Cinema. Exilic \& Diasporic Filmmaking. Princeton: Princeton UP.

Shohat, E. y Robert S.t (1994). Unthinking Eurocentrism. Multiculturalism and the Media. Londres y Nueva York: Routledge.

\section{Filmografía}

Guerrero Felipe (director) (2009) Corta, Colombia: Mutokino

Guerrero Felipe (director) (2006) Paraíso, Colombia: Mutokino

Huertas Laura (directora) (2013) Aequador, Francia, Colombia: Le Fresnoy.

Huertas Laura (directora) (2009) Sin dejar huella, Francia, Colombia: Le Fresnoy.

Huertas Laura (directora) (2012) Viaje a tierra en otrora contada, Francia, Colombia: Le Fresnoy.

Soto Juan (director) (2009) $19^{\circ}$ Sur $65^{\circ}$ Oeste, Cuba, Colombia: Escuela Internacional de Cine y TV San

Antonio de los Baños.

Soto Juan (director) (2014) Estudio de reflejos, Colombia: Tarde o Temprano Films.

Soto Juan (director) (2012) Nieve, Colombia: Cine Corónica - Revista Corónica.

Soto Juan (director) (2012) Oslo (2012), Colombia: Tarde o Temprano Films.

Recibido: febrero 2016/ Aprobado: abril 2016 